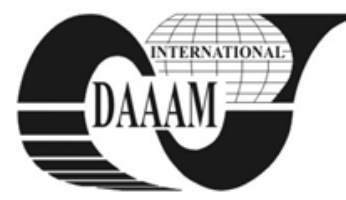

\title{
NEW INFORMATIONAL SYMBOLS FOR HOLDING AND DRIVING MECHANISMS USED FOR MACHINING SHAFTS BETWEEN CENTERS
}

\author{
TONOIU, S[ergiu]; DOICIN, C[ristian] - V[asile]; CATANA, M[adalin] - G[abriel] \& BAILA, D[iana]
}

\begin{abstract}
The paper presents new informational symbols for existing holding and driving elements and mechanisms used for machining cylindrical parts between centers. These informational symbols are not shown in technical literature. Presented informational symbols respect the following technological needs: to suggest the shape of locating element; to indicate the number of degrees of freedom retained to the workpiece through locating; to indicate the type of driving mechanism; to depict the characteristics of preliminary and final clamping mechanisms. These informational symbols are indicated next to technological bases of the shafts that are planes of frontal surfaces and axes of centering holes.

Key words: informational symbols, holding, driving, mechanisms
\end{abstract}

\section{INTRODUCTION}

For processing medium-length shafts $(6 \leq 1 / \mathrm{d}<12)$ or largelength shafts $(1 / \mathrm{d} \geq 12)$ by turning or grinding, commonly used holding schemes include centers or mechanisms with centers (Doicin, 2001). Centers are locators for centering holes of shafts.

Despite that the components of holding and driving mechanisms for shaft machining are described in detail in technical literature, the associated informational symbols are not very well defined for all possible situations (Tonoiu et al., 2003).

So, the purpose of this work is the definition of new informational symbols for holding and driving mechanisms used for machining shafts between centers. To clearly define the informational symbols, their related holding and driving mechanisms are presented nearby. The authors consider that the new informational symbols complete the set of well-known symbols, being useful in defining the location, driving and clamping schemes by machining process planners.

\section{ELEMENTS, MECHANISMS AND SCHEMES FOR HOLDING AND DRIVING SHAFTS MACHINED BETWEEN CENTERS}

Shaft pieces are processed by holding them between the centers in the headstock and tailstock of the lathes or grinding machines. The transmission of revolving motion from the machine's main shaft to the processed workpiece is made by driving mechanism (Joshi, 2003).

Fig. 1 indicates the holding of the workpiece between the dead (non-rotating) center 1 and the live (rotating) center 3 (both located on the centering holes) and the driving of the workpiece through carrier $\operatorname{dog} 4$ and dog plate 5 . Informational symbols of holding and driving scheme are presented in the figure next to constructive sketch (Tonoiu et al., 2003).

When processing axial dimensions of shafts between centers with tools set to fix dimensions, the depth of centering conic holes and the distance between frontal end faces of the shaft have a high importance. In this case, an axial self-adjusting center with locating plate in the headstock of the lathe (fig. 2) have to be used (Tonoiu et al., 2003). The mechanism in fig. 2 includes: body 1 ; locating plate 2 ; self-adjusting center 3 ; spring 4; screw 5; plunger 6 .

A construction with locating and driving plate 2 is shown in fig. 3 .

An other construction, with a dead center 2 and individual driving pins 3 that replace driving plate is presented in fig. 4 (Tonoiu, 2010).

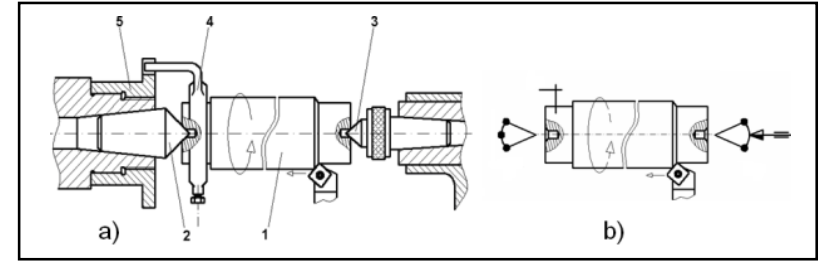

Fig. 1. Holding a shaft between centers and driving with carrier dog: a) constructive sketch b) informational symbols

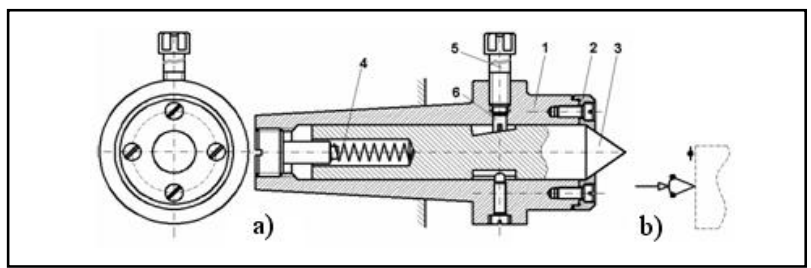

Fig. 2. Self-adjusting center with locating plate: a) constructive sketch b) informational symbols

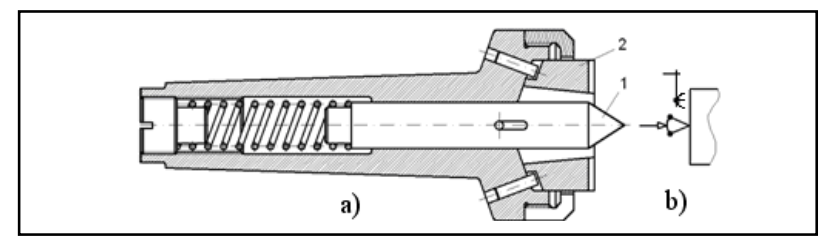

Fig. 3. Self-adjusting center with locating-driving plate: a) constructive sketch b) informational symbols

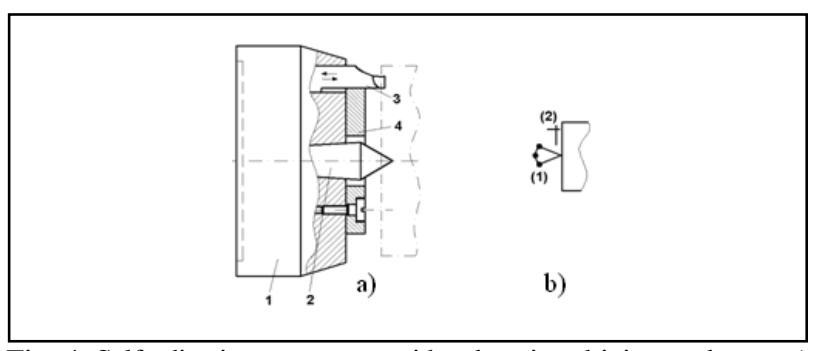

Fig. 4. Self-adjusting center with locating-driving plate: a) constructive sketch b) informational symbols

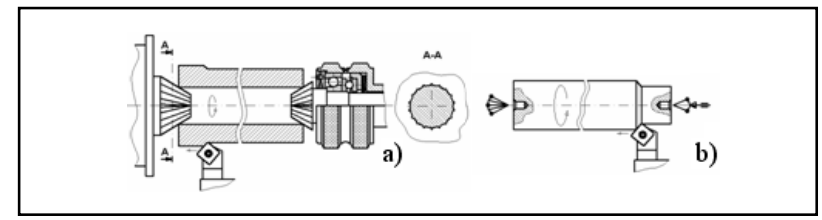

Fig. 5. Self-adjusting center with locating-driving plate: a) constructive sketch b) informational symbols

A solution for driving tubular shafts (fig. 5) applies a knurled dead center in the main shaft of the lathe and a knurled live center in the tailstock (Brăgaru, 1998).

Another driving solution of shafts is by chucks with two or three selfadjusting jaws as shown in fig. 6 (http://www.rohm-products.com, 2011). 


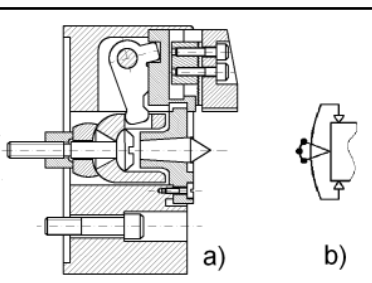

Fig. 6. Two-jaw pneumatically actuated chuck with dead center: a) constructive sketch b) informational symbols

A chuck with self-adjusting jaws can be used also with a locating plate and a self-adjusting center, or with a self-adjusting locating plate and a self-adjusting center (http://www.rohm-products.com, 2011).

\section{DETERMINATION OF HOLDING AND DRIVING SCHEMES FOR MACHINING BETWEEN CENTERS}

Let us consider a turned shaft, with two machined surfaces: a cylindrical surface $S_{2}$ and a flat surface $S_{1}$.

For locating the shaft, several alternative locators may be used and their informational symbols (Brăgaru, 1998) are shown in fig. 7. These alternatives are: dead center (1); self-adjusting center (2) with locating plate (3); self-adjusting center (2) with self-adjusting plate (4). Live center (5) ensures preliminary and final clamping.

Driving the shaft in rotation may be done with (fig. 8): carrier dog (6); knurled dead center (7); driving plate or driving pins (8); chuck with two self-adjusting jaws (9); chuck with three self-adjusting jaws (10). Informational symbols (7), (8), (9), and (10) are designed by the authors to describe existing elements and mechanisms for driving shafts in rotation.

The combination of holding and driving symbols in fig. 7 and fig. 8 gives the set of technically possible holding and driving schemes (HDS) in table 1 . The first ten schemes in table 1 are already applied in industrial practice, and the last two might be, if needed.

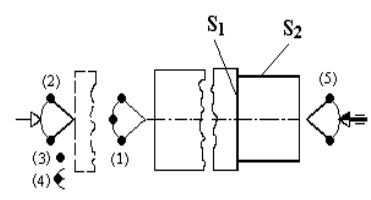

Fig. 7. Technically possible locating and clamping schemes

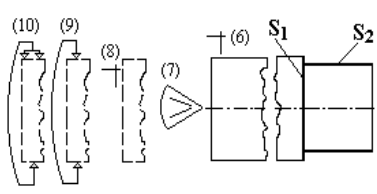

Fig. 8. Technically possible driving schemes

\begin{tabular}{|c|c|c|}
\hline No. & $\begin{array}{c}\text { Holding and driving } \\
\text { scheme (HDS) }\end{array}$ & $\begin{array}{c}\text { Headstock-side holding (H) } \\
\text { and driving (D) } \\
\text { elements/mechanisms }\end{array}$ \\
\hline 1 & $\begin{array}{c}\text { H: Dead center (1) } \\
\text { D: Carrier dog (6) }\end{array}$ \\
\hline & & $\begin{array}{c}\text { H: Dead center (1) } \\
\text { D: Driving pins (8) }\end{array}$ \\
\hline &
\end{tabular}

\begin{tabular}{|c|c|}
\hline & $\begin{array}{c}\text { H: Self-adjusting center (2) and } \\
\text { locating-driving plate (3+8) } \\
\text { D: Locating-driving plate (3+8) }\end{array}$ \\
\hline D: Chuck with two self-adjusting \\
jaws (9)
\end{tabular}

Tab. 1. Technically possible HDS for machining between centers

\section{CONCLUSION}

The paper presents different holding and driving elements and mechanisms for machining shafts in turning and grinding operations. For many of these elements and mechanisms no informational symbols are presented within technical literature. Considering this situation, the work presents a number of informational symbols for holding and driving elements and mechanisms that have centers in their structure. The proposed symbols suggest the shape of locating and driving elements/mechanisms, indicate the number of degrees of freedom retained to the workpiece through location, suggest the type of driving elements/mechanisms, and depict the characteristics of preliminary and final clamping mechanisms.

Data provided by informational symbols permit the making of technical-economical decisions in early stages of process planning activities. Informational symbols suggest also the construction of holding fixtures for turning and grinding operations of shafts, been useful to the planners of workpiece holding devices.

The present work will also eliminate any doubts concerning the usage of locating, clamping, and driving informational symbols for shaft machining in manufacturing process plans.

\section{REFERENCES}

Brăgaru, A. (1998). Proiectarea dispozitivelor, Vol. I, Ed. Tehnică, ISBN 973-31-0717-4, Bucureşti

Doicin, C.V. (2001). Contribuţii la proiectarea asistată de calculator a tehnologiei de prelucrare a arborilor din construcţia de maşini, $\mathrm{PhD}$ Thesis, Universitatea Politehnica din Bucureşti

Joshi, P.H. (2003). Jigs and Fixtures - Design Manual, McGraw-Hill, Inc., ISBN 0-07-140556-9, New York

Tonoiu, S. (2010). Tehnologia fabricării, Partea I, Ed. Bren, ISBN 978973-648-918-1, Bucureşti

Tonoiu, S.; Purcărea, M. \& Catană, M. (2003). Dispozitive şi scheme de prindere pentru prelucrarea pieselor între vârfuri, pe strunguri şi maşini de rectificat. Revista Construcţia de Maşini, No. 1, pp. 7-10, ISSN 0573-7419, Bucureşti

(2011) http://www.rohm-products.com-Holding and Driving Elements and Mechanism, Accessed on: 2011/01/20 